\title{
Schoenoplectus $\times$ flevensis (S. lacustris $\times$ S. tabernaemontani, Cyperaceae) - A nomenclatural correction
}

\author{
Richard V. Lansdown ${ }^{1 *}$; Fred Rumsey ${ }^{2}$ \\ ${ }^{1}$ Associate Researcher, Natural History Museum, London; ${ }^{2}$ Senior Curator, Natural \\ History Museum, London
}

*Corresponding author: Richard V. Lansdown: rvlansdown@gmail.com

This pdf constitutes the Version of Record published on $7^{\text {th }}$ December 2020

\begin{abstract}
Additional detail is provided to validate the new combination Schoenoplectus $\times$ flevensis (D.Bakker) Lansdown \& Rumsey comb. \& stat. nov.

Following our recent paper on the presence of the hybrid between Schoenoplectus lacustris (L.) Palla and S. tabernaemontani (C.C. Gmel.) Pallain the British Isles (Lansdown \& Rumsey, 2020) in which we made a novel combination for this hybrid, it has been pointed out to us that our name was not validly published because a "full and direct reference given to its author and place of valid publication, with page or plate reference and date" was not provided as stipulated in Art. 41.5 (Turland et al., 2018). In order to correct this oversight and validate the new combination we address this below.
\end{abstract}

Schoenoplectus $\times$ flevensis (D.Bakker) Lansdown \& Rumsey comb. \& stat. nov. Basionym: Scirpus lacustris subsp. flevensis D. Bakker (1954) Acta Botanica Neerlandica 3(4): 434.

Holotype: Ketelveld, bij de uitmonding van de Yssel (Flevoland), ondiep uoet water, Netherlands, 1 July 1953, Bakker, D. 1153 (L 0442940).

$S$. $\times$ flevensis is most readily recognised by possessing a stem size typical of $S$. lacustris but (usually) glaucous in colour, combined with lax and open panicles due to the length of the secondary branches. In British plants the anthers are typically $<2 \mathrm{~mm}$, often withered and empty, in contrast to both parents.

\section{References}

Lansdown, R.V. \& Rumsey, F.J. 2020. Schoenoplectus $\times$ flevensis (S. lacustris $\times$ S. tabernaemontani, Cyperaceae) in the British Isles. British \& Irish Botany 2(3): 190-201.

Turland, N. J., Wiersema, J. H., Barrie, F. R., Greuter, W., Hawksworth, D. L., Herendeen, P. S., Knapp, S., Kusber, W.-H., Li, D.-Z., Marhold, K., May, T. W., McNeill, J., Monro, A. M., Prado, J., Price, M. J. \& Smith, G. F. (eds.) 2018: International Code of Nomenclature for algae, fungi, and plants (Shenzhen Code) adopted by the Nineteenth International Botanical Congress Shenzhen, 
China, July 2017. Regnum Vegetabile 159. Glashütten: Koeltz Botanical Books. DOI https://doi.org/10.12705/Code.2018

Copyright retained by author(s). Published by BSBI under the terms of the Creative Commons Attribution 4.0 International Public License.

ISSN: $2632-4970$

https://doi.org/10.33928/bib.2020.02.407 